\title{
Formation of Hot Water Springs in Sri Lanka
}

\author{
H.M.R. Premasiri, D.S. Wijeyesekera, S. Weerawarnakula and \\ U.G.A. Puswewala
}

\begin{abstract}
As a wonderful gift of nature, several hot water springs occur in Sri Lanka, though it is not situated within a very active tectonic zone of the earth. The present research was conducted to model the formation of hot water springs in Sri Lanka based on geological and tectonic settings by using geological, geophysical and remote sensing techniques. It is found that the major boundary between Highland Complex and Vijayan Complex show multiple thrust planes and shear zones showing imbrecated lithological slices of both Highland Complex and Vijayan Complex. Other than the ductile structures, brittle fractures, joints and fault planes extend as mega lineament for several kilometers. These lineaments produce good secondary aquifer conditions with adequate porosity. The surface mapping and geophysical evidence of the lineaments show that they are very deep and interconnected. Thus it is proposed that structurally controlled hot water springs in Sri Lanka are associated with deep geologically weak zones of fracture or fault systems within the thrust boundary which shows some neo-tectonic activities.
\end{abstract}

Keywords: hot-water springs, Sri Lanka, thrust boundary, lineaments, fractures, faults, geological model.

\section{Introduction}

Several hot water springs are located mostly in the eastern part of Sri Lanka. Generally, hot water springs in the world are commonly associated with volcanic terrain. But hot water springs in Sri Lanka do not have any relation to volcanic activities, since the island is located in an area free of volcanic activity. Therefore, the formation of hot water springs in Sri Lanka is an interesting phenomenon to investigate based on the geological setting of the area.

First records and pioneering work on hot water springs in Sri Lanka were made by Parson (1907) and Danial (1908). Hot water springs at Mahapelassa off Embilipitiya, Kanniyai off Trincomalee and Mahaoya are well known to people. These thermal springs have their outflow temperature ranging between $34^{\circ} \mathrm{C}$ and $56^{\circ} \mathrm{C}$ and lie close to the boundary between Highland-Vijayan lithologic Complexes (Figure 1) consisting mainly of crystalline metamorphic rocks (Cooray, 1984). The hottest springs lie at Kapuralla $\left(56^{\circ} \mathrm{C}\right)$, followed by Mahaoya $\left(55^{\circ} \mathrm{C}\right)$; Mahapelassa $\left(44-46^{\circ} \mathrm{C}\right)$ and Marangala-Wahawa close to Padiyatalawa $\left(42-45^{\circ} \mathrm{C}\right)$; Nelumwewa which was known earlier as Madawewa is now under a lake, and records $45^{\circ} \mathrm{C}$ in mud samples (Fonseka 1994). Recently two hot -springs were reported at Weherapokuna within the Ulhitiya national park and Adampane (Cooray 1984, Dissanayake and Jayasena 1988, Fonseka 1994). Table 1 lists the currently known hot water springs in Sri Lanka.
H. M. R. Premartri - B.SC. (Honse)(Penadenlyat, M.Phil.,(Momtuwa); is a Lecturer in the Department of Earnh Ressources Englineerhs, Unlversing af Moraturwn, Sri Lanton, currently neading for his docooval degree at Keeds University. UK. He wras formerly autached to the Geolugionl Survey and Mines Bureau of Sri Larka. His resenrch interests are in the Selds of Gedosy and Remole Sensing \& GIS.

Eng. (Praf.) D. S. Wijeyesekera - D.Lin.(OUSL). D.Univ(OUUK).

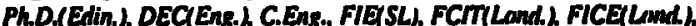
FNAS(SL): is a Senior Pmfessor of ClWll Englneering as the Univerdity of Moratrma, Sit Lantan He was formenty the Vice Chanrellor of the Open Universiry of Sri Lanke, and the Mee Chancellor af the Univeratly of Monatuwa He is a former President of the Institution of Englneers. Sn Lanks. His reseonch interests are in the fields of Hydraulies Engineering. Groundwrater and Trunsportation Enstheering.

S. Wearmernakula - B.Sc(SLL. M.Phill.(Ibdan): is a Sentor Lerruner in the Depanment of Enrth Resources Ensineering. He was formenty the Hend of the Deparment of Eanth Resourres Englneering. Universilys of Moratumen, and the Directior of the Genlogical Survey and Mines Burenu

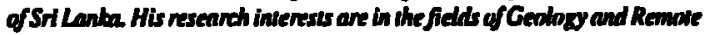
Sensing \& GIS.

Eng. (Dr.) U.G.A. Puswewale - B.Sc.(Eng.) (Hans. MMomnuwn), M.Eng.(AIT, Ph.D. (Manlioba), C.Eng., MIE (SL) ; is a Sentor Lerturer in the Depanment of Clvil Engineering, and rumensly the Head of the Depanment of Eanth Resources Engineering. Untuerdity of Marnmoner.

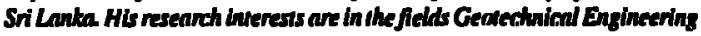
and Remore Sensing \& GIS. 
Table 1: Hot water Springs in Sri Lanka

\begin{tabular}{|l|c|}
\hline $\begin{array}{c}\text { Location of Hot water } \\
\text { spring }\end{array}$ & $\begin{array}{c}\text { Out flow temp- } \\
\text { erature }\left({ }^{\circ} \mathrm{C}\right)\end{array}$ \\
\hline Mahapelassa & 44.9 \\
Kanniyai & 42.0 \\
Rathkihiriya & 42.0 \\
Kapurella & 55.0 \\
Mahaoya & 54.2 \\
Planoya (Jayanthiwewa) & 34.1 \\
Wahawa( Padiyatalawa) & 46.8 \\
Nelumwewa & 45.0 \\
Adampane & $*$ \\
Weherapokuna & $*$ \\
\hline
\end{tabular}

* Not measured yet

The thermal springs of Sri Lanka are a manifestation of the earth's internal heat, and its potential for our consumption is not yet investigated properly. The future use of geothermal energy in Sri Lanka can vary from power generation to industrial, agricultural and domestic uses and the tourist industry (Fonseka, 1994).

\section{Investigation and environments of hot water springs}

Geological, geophysical, and geochemical exploration techniques and the remote sensing method can be used to investigate the formation of hot water springs. Occurrence, nature and properties of heat sources or geothermal sources in the earth depend on geotectonics and the geological structure underneath. Therefore, an integrated effort is more appropriate for the geothermal investigation process. In this work, geological investigations such as field mapping and remote sensing interpretations were used to prepare subsurface geology and geological structures at both local and regional scales. Hydrogeochemical investigation of the hot water springs plays a major role in understanding the condition of a geothermal system as all geochemical properties of hot water are controlled by the surrounding underground environment and the source of origin of hot water. Special isotope analyses give most of the information regarding the source of origin such as meteorologic water or underground water. Normally, high enthalpy volcanic regions and rift valleys are highly potential areas for geothermal resources.

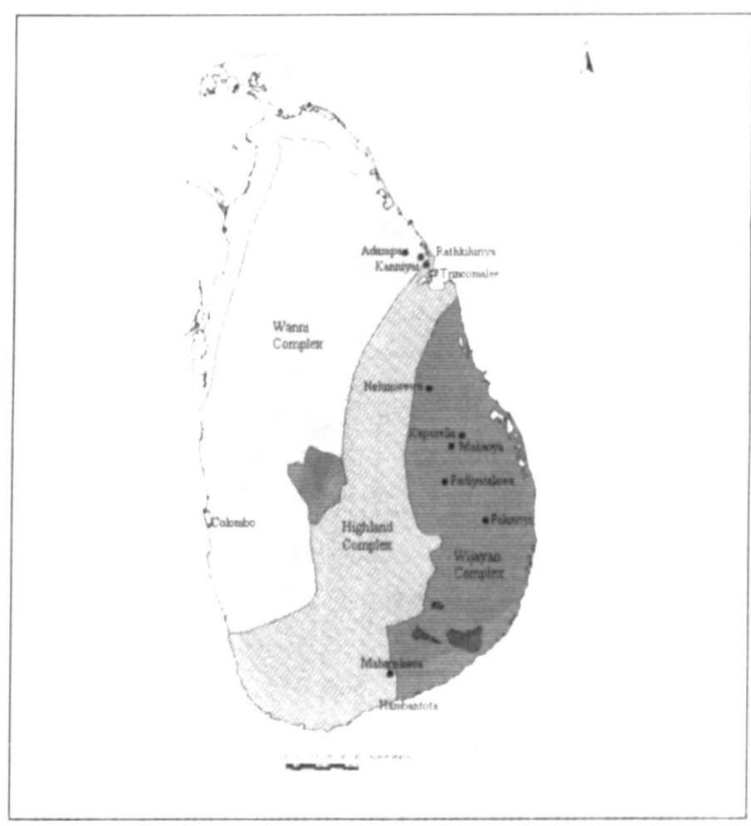

Figure 1. Geology map of Sri Lanka showing locations of hot water springs (Cooray, 1994)

Presently, three environments are generally accepted to lead to the formation of most of the hot water springs in the world. They are: 1. Tectonically active or inactive deform zones; 2 . Environments associated with volcanic activity; and 3 . Environments associated with radio active zones. In all these environments, the common feature is the relatively high geothermal gradient, which is a key factor for the formation of hot water springs.

\section{Geological and Tectonic Setting of Hot Water Springs in Sri Lanka}

Nine tenths of Sri Lanka is underlain by Proterozoic Metamorphic rocks. The remaining ten percent is mostly Phenerozoic and Recent sedimentary rocks and superficial deposits. Recent $\mathrm{Nd}$ model ages, high- precision U-Pb zircon ages (Millisenda et al. 1988, Holzl et al. 1991) and $\mathrm{Rb}-\mathrm{Sr}$ age dates indicate that Sri Lanka's evolution during the Proterozoic occurred essentially by the tectonic assembly of three distinct crustal units which are distinguishable by tectonic setting, geochronology and geology. These three units are named as (1). Highland Complex (formally, Highland South Western Group, Highland Series, Central Granulite Belt) (2). Wanni Complex (formally Western Vijyan Series), and (3). Vjayan Complex (formally Eastern Vijayan Series); (Cooray 1994). 
This Proterozoic rock terrain represents a small portion of the Gondwana super continent. Sri Lanka was juxtapositioned with India, Antarctica, Madagascar and Mozambique in Gondwana super-continent. Evolution of Gondwana super continent and reconstruction has been subjected to much debate. However, it has been explained by using recent paleomagnetic and geologic data (Yoshida and Vitanage 1993). Jurassic and CambroOrdovician paleomagnetic pole position deduced from rocks of Sri Lanka and Antarctica conform approximately when Sri Lanka moved and rotated to juxtapose with Lutzow-Holm Bay.

Geophysical, geochemical and remote sensing studies were carried out in an integrated attempt to understand the geological and tectonic setting of the areas of hot water springs in Sri Lanka. Based on the results of these investigations, a conceptual geological model is developed to explain the formation of hot water springs of Sri Lanka.

\section{Geological setting of Highland Complex-Vijayan Complex boundary}

Geological field mapping, structural geological analysis, geophysical investigation and other aerial photographic and satellite image interpretation are used to describe the geological structural evolution in the area. The granulite facies ( $2.0-1.85 \mathrm{Ga}$ isotope ages) and Amphibolite (1.1- 1.0 Ga ages) are two major metamorphic rock terrains at the boundary that are extremely vital to explain the Sri Lankan Geology. Available geophysical data elucidate that rocks in the Highland Complex show a slightly higher density of 0.05 to $0.1 \mathrm{~g} / \mathrm{cm} 3$ when compared to the adjacent rocks of Vijayan Complex. This higher density may be due to the abundance of basic rocks and garnet- sillimanite gneiss (khondalite). Mineralogically, presence of higher contents of mafic minerals or Fe-Mg rich minerals and garnet would be the reason for having a higher density. The higher density of rocks result in the gravity anomaly shown in the gravity map of Sri Lanka compiled by Hatherton et al. (1975). The concept of a simple thrust boundary between Highland Complex and Vijayan Complex is well established by various studies (Vitanage 1972, Kroner et al.
1991), and many other geological mapping programmes conducted by the Geological Survey and Mines Bureau (GSMB) of Sri Lanka. The mapping of the southern part of the boundary consisting of the area around Mahapelassa hot water spring and Haputale, Thimbolketiya and Ambalantota (1:50000 map sheet area) helped to interpret much of the geological, structural and tectonic behavior of the HC- VC boundary.

Careful studies of the rocks in the two tectonic complexes show obvious differences such as geochronological, mineralogical, structural, textural and geomorphological features (Kroner 1991). Generally, the Highland Complex area is characterized by high relief and elevated ridge and valley topography. A very complex sequence of deformational and metamorphic events at deep crustal level resulted in the highly complicated and deformed nature of the rocks in this complex than in the case of the Vijayan rocks. Lithologies in the Highland Complex are predominantly highly tectonized gneisses which were metamorphosed under granulite facies condition. Major rock types found in the Highland Complex are ortho and para charnockite and charnockitic gneisses, garnet-sillimanite-gneisses+graphite, crystalline limestone with calcitic and dolomitic composition and meta quartzite. This lowest lithological sequence of the Highland Complex is formed as a very steep escarp slope (example: Kaltota escarpment) and is a sudden break of the regional geomorphology.

Field observations revealed that the area has been subjected to a sequence of tectonic events at various crustal levels. A major trend of lithological layering of the southern part of the boundary is in the NW-SE direction which coincides with the direction of the boundary. Also the direction of trends of lithological layering changes through the boundary zone but it mostly follows the direction of the boundary zone. The lithlogical sequence of the area is very often duplicated due to folding, refolding during various deformational events and the presence of several thrust planes. The gently dipping, tectonically repeated D2 sequence has been further complicated by subsequent refolding due to continued ENWESE shortening, producing a hook shaped fold and paired synform and antiform upright fold (D3) of large scale. Subsequently, by a late event, 
limb areas of these large folds have been sheared and have mostly disappeared.

Vijayan Complex is bound to Highland Complex at the east by the formation of a flat ground. Vijayan Complex contains variably migmatized amphibolite grade gneisses. Hornblend-biotite gneiss with composition ranging from gabbro, diorite to synogranite, and granitic and granotoid gneisses are major Vijayan rocks found in the area. The para gneisses found in the Vijayan Complex are only in minor amounts. The zone between Highland and Vijayan Complexes has a transition zone which can be clearly recognized by mapping of the area. This transition zone comprises of rocks belonging to both lithotectonic complexes (Figure 2).

Although previous studies confirmed a well defined boundary between $\mathrm{HC}$ and VC in the form of a single horizon boundary (Cooray 1985, and Vithanage 1972), present field information suggests that there is a transition buffer zone of partially or weakly migmatized to fold banded charnockite gneisses extending over tens of kilometers. The cross section of the boundary zone shows multiple thrust planes as an imbricate thrust boundary consisting of slices of both Highland Complex granulites and Vijayan Complex amphibolite grade gneisses. In the transition zone between $\mathrm{HC}$ and $\mathrm{VC}$, following features can be observed from Highland to Vijayan direction:

1) Disappearance of charnockitic nature of the rocks.

2) Occurrence of more hornblende rich gneisses.

3) Increasing of migmatization.

4) Decreasing of complexicity of geological structures.

The major geological feature of the eastern part of Sri Lanka is the HC- VC boundary zone having multiple thrust planes, and shear zones showing imbrecated lithological slices of both Highland Complex and Vijayan Complex. In addition there are ductile structures, brittle fractures, joints and fault planes occuring as mega lineaments extending several kilometers. These lineaments have produced good secondary aquifer condition with adequate porosity. The surface mapping and geophysical evidences (Fonseka 1994) of the lineaments show that they are very deep and interconnected. Therefore they offer a better pathway for percolating surface water to reach depths and return upwards with adequate pressure to reach the surface

Other general geological features seen in the boundary zone are the presence of geothermal activities or hot water springs, igneous intrusions (serpentinite, dolerite dykes), pegmatites and other vein type mineralizations.

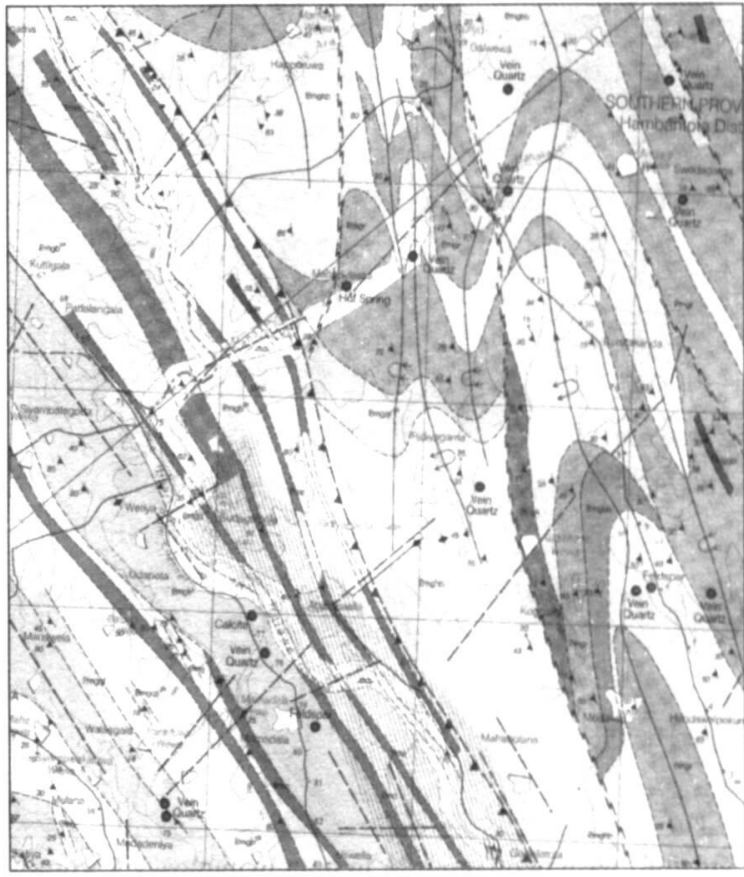

Figure 2. Geological map of Mahapelassa area showing boundary zone between HC and VC ( Source GSMB)

All these evidence show that the boundary between Highland Complex and Vijayan Complex of Sri Lankan litho-tectonic subdivision is a tectonically active minor boundary and is a geologically weak zone. Therefore, a fairly high geothermal gradient can be expected in this zone when compared with similar tectonic areas in the world e.g. Mozambique belt.

\section{Lineaments in Sri Lanka}

Lineaments of regional scale running N-S, NNW-SSE, NNE-SSW and E-W directions have been recognized in Sri Lanka by various studies (Vitanage 1972). Recently, tectonically active lineaments were recognized in Sri Lanka by analysing micro seismic activities and by using Land-sat images (Kehelpannala 2003). The deep 
fractures, fault and joint systems dissect the mini crustal unit of Sri Lanka into a rectangular and rhomboidal mosaic. They show distinct horizontal (maximum 50-350m) and vertical (10$15 \mathrm{~m}$ ) displacements. The field studies of these lineaments in many parts of Sri Lanka indicate that most of the lineaments are wrench fault or strike-slip faults with lateral displacement. In addition, well defined mega lineaments also occur in the off-shore, e.g. in the area running through Palk Straits, NE-SW fault zone with transverse submarine "Valley and Ridge" (graban and host) structures mark the divergent rift boundary of south India and Sri Lanka. Other significant mega lineaments include the N-S lineament of Pondicheri - MannarPuttalam.

There is much evidence to support the proposition that the neo-tectonic movements are mainly associated with lineaments, faults and fracture zones. During the Mahaweli project the micro-seismic network around Kotmale, Randenigala and Victoria projects recorded over 500 micro seismic events (since 1982) with magnitude ranging from 0.2 to 2.25 on the Richter scale. The coincidence of many epicenters of these micro-seismic events with the existing lineament pattern shows a clear relationship between micro-seismicity and lineament related neo-tectonic movements in the area and also indicate that many lineaments are active. Other than these events, mega earthquakes occurring in the west, south and east of Sri Lanka (e.g. around Sumatra Island) were felt by sensitive persons in Sri Lanka in the recent past and the pattern of seismic wave travel shows a connection with lineaments in the Sri Lankan crust.

\section{Geochemical parameters of hot waters}

According to geochemical parameters (Figure 3), Kapurella, Mahaoya and Padiyatalwa show similar conditions with chloride, sodium, magnesium, and potassium concentrations being almost similar. But Mahapelassa shows an exceptionally high content of chloride, fluoride and bicarbonate compared to other locations. Kanniyai hot water spring has very low salt concentration with respect to the others.

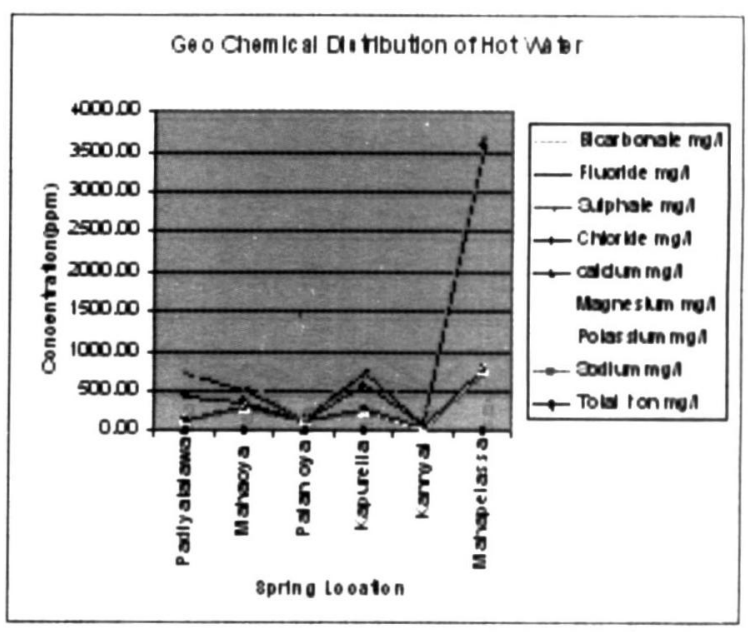

Figure 3. Geochemical characteristics of hot waters in Sri Lanka.

\section{Model}

Most of previous interpretations of formation of hot water springs in Sri Lanka have indicated a relationship with the HC-VC boundary but they mostly considered heat from shallow intrusive igneous activities only. Also most of them (Fonseka 1994) considered that hot water rises through single deep thrust zones such as weak geological boundaries. But the present study reveals that hot water springs in Sri Lanka are mostly related to HC-VC boundary zone, and deep-seated mega lineament present in the areas. Some springs have hot waters of similar nature, indicating a similar source of origin. Therefore it can be hypothesized that multiple thrust planes and a major tectonically active zone generate heat sufficient to increase the geothermal gradient, and surface water percolating through available deep-seated fractures are heated up. Subsequently, the pressure in the fracture is increased by formation of steam and the hot water travels up through intersecting fractures which are readily available in the area. This water reaching the surface can be contaminated with available chemical constituents as well as cool ground water, occurring in the flow path in different amounts and at different levels. This mechanism is mostly similar to the formation of hot water springs of the Rocky Mountains in Canada.

\section{Conclusions}

Neo-tectonic activities along multiple thrust boundary between $\mathrm{HC}$ and $\mathrm{VC}$ are the reasons for formation of hot water springs in Sri Lanka. The water of these springs are meteoritic waters 
i.e. surface water percolates through deep fractures and return after being heated by geothermal energy at depth. According to geochemical parameters and geological and geographical setting, hot water springs in Sri Lanka can be divided into three groups as follows:

\section{Group 1 : Mahapelassa.}

Group 2 : Kapurella, Mahaoya, Padiyatalwa, Palanoya and springs around Mahiyangana and Ampara.

Group 3 : Kanniyai, Rathkhiriya and Adampane areas.

The hot water spring of Group 1 is located in the southern part of Sri Lanka and mostly towards HC side of the HC-VC boundary zone. Geochemically it shows a high salt content (Figure 3). Hot springs belonging to Group 2 fall in the eastern part of Sri Lanka and are located mostly on the VC side of the HC-VC boundary zone. The waters in this group have low content of salt. Hot water springs in Group 3 are located in the northeastern part of Sri Lanka and mostly to the HC side of the HC-VC boundary. They also show very low content of salt.

According to the proposed model, there are possibilities for more locations where hot water springs may occur in Sri Lanka, specially in the HC-VC boundary zone, mostly along the mega lineaments. Hot water springs in Sri Lanka do not show any relation to volcanic activities. Based on this model it is recommended to carry out more explorations along major fractures or lineaments in these areas.

\section{References}

1. Cooray P.G., 1984, An introduction to the Geology of Sri Lanka. National Museum of Ceylon, Colombo.

2. Cooray P.G.,1994, The Precambrian of Sri Lanka: a historic review. Precambrian Research, volume 66, pp 3-18.

3. Danial J.A., 1908, Cold and hot springs. Ceylon Administrative Report Part 4/ Education, . Science and Arts, E3.

4. Dissanayke, C.B. and Jayasena H.A.H., 1988, Origin of Geothermal system of Sri Lanka. Geothermics, volume 17, No.4, pp 657-669.

5. Fonseka G.M., 1994, Geothermal System in Sri Lanka and Exploration of Geothermal Energy.
Journal of the Geological Society of Sri Lanka, volume5, pp 127-133.

6. Fonseka J.P.R., De Silva N.R., Balendran U.S. and Senevirathne L.K., 1963, Mineral and thermal waters of Ceylon. International Geological Congress, volume 19, pp 9-19.

7. Hatherton T., Pattiarachchi D.B. and Ranasinghe V.V.C., 1975, Gravity map of Sri Lanka. Professional paper No. 3, Geological Survey Department, Sri Lanka.

8. Holzl S., Kohler H., Kroner A., Jaeckel P. and Liew T.C., 1991, Geochronology of the Sri Lankan Basement. The crystalline crust of Sri Lanka: Part 1, Professional Paper No.5, Geological Survey Department, Sri Lanka, pp 237-258.

9. Kehelpannala K.V.W., 2003, Structural evolution of the middle to lower crust in Sri Lanka _ a review, Journal of the Geological Society of Sri Lanka, volume 11, pp 45-85.

10. Kroner A., Cooray P.G. and Vitanage P.W.,1991, Lithotectonic subdivision of the Basement in the Sri Lanka. The crystalline crust of Sri Lanka: Part 1, Professional Paper No.5, Geological Survey Department, Sri Lanka, pp 5-21.

11. Milisenda C.C., Liew T.C., Hofmann A.W. and Kroner A, 1988, Isotopes mapping of provinces in Precambrian high grade terrains: Sri Lanka. Journal of Geology, volume 96, pp 608-615.

12. Parson J., 1907, Cold and hot springs, Ceylon Administrative report part 4/ Education, Science and Arts, E3.

13. Vitanage, P.W., 1972, Post Precambrian uplifts and regional neotectonic movements of Ceylon. 24th International Geological Congress, Canada, Section 3, pp 642-654..

14. Yoshida M. and Vitanage P.W.,1993, A review of the Precambrian geology of Sri Lanka and its comparison with Antarctica. Gondwana 8th Assembly, Balkema, Rotterdam, pp 97-109. 